\title{
Media Development Learning Ladders Snakes Educative Subthemes Plants For First Grade Elementery School
}

\author{
Winarti Agustina ${ }^{1}$ \\ ${ }^{1}$ Early Childhood Education, Institut Agama Kristen Negeri Tarutung, Tapanuli Utara, Sumatera Utara, \\ Indonesia \\ Corresponding Author. E-mail: \\ 1winarti1708@gmail.com
}

Received: January $2^{\text {nd }}, 2020$

Accepted: January $28^{\text {th }}, 2020$

Online Published: January 31 ${ }^{\text {st }}, 2020$

\begin{abstract}
Fun educational learning media rarely exist in the elementary school environment . So this study aims to develop educational learning media snake ladder with plant theme for firist grade elementery school. This research was conducted in three elementery schools in Bekasi. The method used is a research and development model with Borg \& Gall. The results show aspects of media needs only $25 \%$ of teachers using games in learning media. While as many as $83 \%$ of teachers think the learning material in the book is very supportive theme to use instructional media. Researchers also conduct tests to students about the concept of living things, especially plants with an average value of 43.33 which enter into the category of "less". Based on these findings, the researchers conducted the development of instructional media educational ladder snake plant subthemes. This medium-sized $2 \times 3.5 \mathrm{~m}$ where each field contains information about the plant concepts that are tailored to the learning curriculum. Students also are directly involved with being pawns and dice made from flannel made safe with the size $30 \times 30 \mathrm{~cm}$.
\end{abstract}

Keywords: learning media; snakes and ladders; plants; early childhood

How to cite this article :

Agustina, W. (2020). Media Development Learning Ladders Snakes Educative Subthemes Plants For First Grade Elementery School. IJIS Edu : Indonesian Journal of Integrated Science Education, 2(1), 43-54. doi:http://dx.doi.org/10.29300/ijisedu.v2i1.2645 


\section{INTRODUCTION}

Children of the early grades of Elementary School are the one who are in the age range of 6-9 years old. Based on its stages, elementary school is in the concrete operational stage where children learn from what they see, hear, smell, touch, and try, stressing on the utilization of the environment as the source of study. In alignment to this, a research conducted by Shukla Sikder and Marylyn Fleer (2015:446) states that "it can be argued that if children learn scientific concepts from an early age through everyday practices ..." therefore, the formation of science concepts is started from the daily activities within the child's environment.

Science for children is an incredible thing that is found and regarded as attractive. It stimulates them to get to know or even explore more about it. Based on its fundamental factor, the study of science has a big influence for the early childhood development.

A research conducted by Barbara et al. (2016:83) shows that children's curiosity is useful for them in experiencing science, and it facilitates them to develop their skills and intellectuals. Based on this, the improvement of science study on children remains important in putting the foundation for being an understanding and competence human being. Therefore, science learning is expected to be given in the earliest age.

Based on a research by Haley A. Vlach and Nigel Noll (2016:317), it is pointed out that "adults in children's environment, such as parents, teachers, and caregivers, play an instrumental role in guiding children's learning and thinking". This statement shows that adults' guidance is one of the ways to take the children to be the best generation in the future. Children need guidance from adults who are considered as worthy person to help them develop and learn enjoyable learning experience.

Guidance of the adults or teachers to the children should be in line with the contents of science. Mesut Sackes (2014:171) explains that contents of science based on his research consist of three different contents, "there are three, common content areas across the state science content standards developed for early years: physical science, earth and space science, and life science". Those three contents are the foundation in building children's comprehension skills.
According to the data of Trend in International Mathematics and Science Study (TIMSS) (2015:2-3) towards elementary students in the field of science, Indonesia is ranked in the 45th of the 48 nations with 397 points. Based on the content of cognitive aspects in science, Indonesian's students are remained low. The survey proves that the study of science is still facing a problem. Hence, an ideal number of science learning should be given in the earliest time.

The researcher interested to modified snakes and ladders board game with plants subtheme that have been adjusted to be suitable with the students' age. According to Agus (2011:106), snakes and ladders is a board game that is played by one or more persons. The board is divided into small boxes in which some snakes and ladders are drawn to connect one box to the other.

The difference of this game from the others common board games is the interactive contents of plants as the sub theme of the game that has been customized to the standard national science education and the Ministerial Regulation of National Education (Permendiknas) No. 22 Year 2006. Based on that, it is generated that the contents concept of plants are; (1) Characterization of plants, consists of classification, basic needs, structure and functions of the plants; (2) plant reproduction; (3) plant habitats; (4) plant's ability to adapt with the other plants and its surroundings; (5) plant life cycle.

Besides that, audio and visual are added to support the children's understanding (Agustriana, 2019). There are also some challenges, answer keys, and a collection of activities in the back of the board game. This educative board game is expected to increase the children's motivation in learning science as this game supports them to learn in enjoyable way without them realizing it.

The purpose of the study is to identify the media of study that is currently used in learning science, especially in the sub theme of plants, to know the children's level of knowledge to the concept of plants, and to develop the leaning media of snakes and ladders board game with sub theme of plants for first grader students in Elementary Schools in Bekasi.

\section{RESEARCH METHOD}


This research is a study that aimed to develop products through certain procedures or steps. The researcher uses Borg \& Gall's model (2013:163) to do and elaborate this research. Subjects for the data collection are the first grader elementary school's students and teachers in Bekasi. Data collection's instruments are observation sheets, interviews, questionnaires, and documentation The theory developed by Borg and Gall has steps that have been well tested (Amin, Wiwinda, Alimni, \& Yulyana, 2018; Borg \& Gall, 1983; Irwandani, Umarella, Rahmawati, Meriyati, \& Susilowati, 2019; Khoirudin, 2019; Leriyono, Kurniah, \& Ardina, 2018; Minarti, Susilowati, \& Indriyanti, 2012; Saregar et al., 2019; Selviani, 2019)

\section{RESULTS AND DISCUSSION}

The development process of this learning media is taken by examining various literatures, taken from related books and journals about learning through educative board games. Afterwards, observation is conducted in three elementary schools in Bekasi. Based on the observation, it is found that the media used in learning is less varied, lecturing is the most common method in learning, and students are not actively involved despite some students tend to be active in class. This research is observed by these steps as follow (a) observe the classroom environment, both physically, socially, and interactively; (b) observe the learning outcomes of students during learning activities, in this case the researcher notes important things that happened and done by the students; (c) discuss the result of the observation with teachers and school principals, to seek approval for a diagnosis;

The researcher interviewed 12 teachers to find out the availability of learning media and the teachers' expectations regarding to learning media. The result of the interview shows that $25 \%$ of the teachers used games as the media for learning, and $83 \%$ of the teachers claimed that learning materials in the themed book support to be used through media. Data from the teachers' expectations showed 92\% teachers supported the making of snakes and ladders board game with sub theme of plants as an effective media for learning.

An observation was also conducted through evaluations. The aim of this evaluation is to gather information about the understanding of the first grader students about plants. Data are gathered through evaluations of students' objective test results regarding to the concept of plants, in average students got $43.33 \%$. The average results are then conversed into conversion table.

The conversion table for scores (Suharsimi, 2009:245), numbers, and alphabets are in table 1.

Table 1. Score Conversion

\begin{tabular}{ccccc}
\hline Number 100 & Number 10 & IKIP & Alphabet & Description \\
\hline $80-100$ & $8,0-10,0$ & $8,1-10$ & A & Excellent \\
\hline $66-79$ & $6,6-7,9$ & $6,6-8,0$ & B & Good \\
\hline $56-65$ & $5,6-6,5$ & $5,6-6,5$ & C & Fair \\
\hline $40-55$ & $4,0-5,5$ & $4,1-5,5$ & D & Poor \\
\hline $30-39$ & $3,0-3,9$ & $0-4,0$ & E & Bad \\
\hline
\end{tabular}

Based on the score conversion table, the level of the students' understanding about concept of living this is categorized as "Poor".

From that result of the students' needs analysis, the researcher concluded an analysis with these following results:

1. Science is only used as the source of readings.

2. Learning media is less varied, and there is no media that could measure children's understanding on the concept of the living things.

3. Playful learning media is needed to fulfill the needs for learning in the plant subtheme for the first grader students through the media of educative board games.

Based on that analysis, the researcher did an improvement through learning media of educative snakes and ladders board game with plant subtheme. This learning media is an innovation to the common board games which its main components are drawing plots, pawns, and dice. According to Nurjatmika (2012: 103), the design for snakes and ladders board game has no standard, so everyone could make their own attractive board games. This argument becomes the foundation of the development of 
educative board games that are suitable for children. In this board game, there are 20 small boxes that are made in the consideration of numeric identification by the Standard Competency and Basic Competency (SKKD) of mathematics by Permendiknas No. 22 Year 2006. In alignment to this, Richard D. Kellough (1996:196) argues that teachers could introduce numeral to the first grader students from 1 to 10 , and 11 to 20 . The board game contains information about plant concepts that are presented in each game plot, there are challenges, answer keys, and collection activities behind the educative snakes and ladders board game.

Besides it contains information about the concepts of plants (Samatowa, 2010:52), the educative snakes and ladders board game is also designed based on the children's development in the age of $6-8$, in which according to Yuliani (2009: 161: 162) the development of motoric skills in that age, a child could jump from a height of $20 \mathrm{~cm}$, throw things with both hands, draw human with complete body parts, draw according to the vision, and imitate sentences in handwriting. Based on that explanations, the educative snakes and ladders board game is played by jumping from on box to the others and the collection of activities helps to train the children's motoric.

Furthermore, Yuliani (2009:162) explains that the children's cognitive skills in the age of 6-8 can recognize values of place, distinguish words that share similarities, and able to understand the concept of geometry, and puzzles. Based on that, the educative snakes and ladders board game serves boxes of challenges and designs a geometrical dice.

On language and social skills, Yuliani (2009: 162-163) explains that children of 6-8 years old are able to master around 14,000 words, tells stories, and understand that word has meaning and function. Children are able to tell story of their drawings, reading out loud, and answering questions. This is the basic development to design rules while playing.

Innovations in this educative snakes and ladders board game with plants subtheme as seen from the game design, conditions, and rules are here as follow:

(1) Media tools for the educative snakes and ladders board game with plants subtheme

A board game consists of drawing and small boxes, printed on banner in size of $2 \times 3,5$ $m$. Each box is filled with information that should be read aloud by the players or press the speaker image to listen the audio information from the players. There are also some boxes that contain challenges that should be answered. Those answers are placed in the back of the box, if the player answers it correctly, he/she will get 1 point, but if the players couldn't answer it, he/she will not get any points. The pawn of this game is the players. The dice was made from a flannel base material with geometry shape (circles, squares, and triangles) on the top of the dice

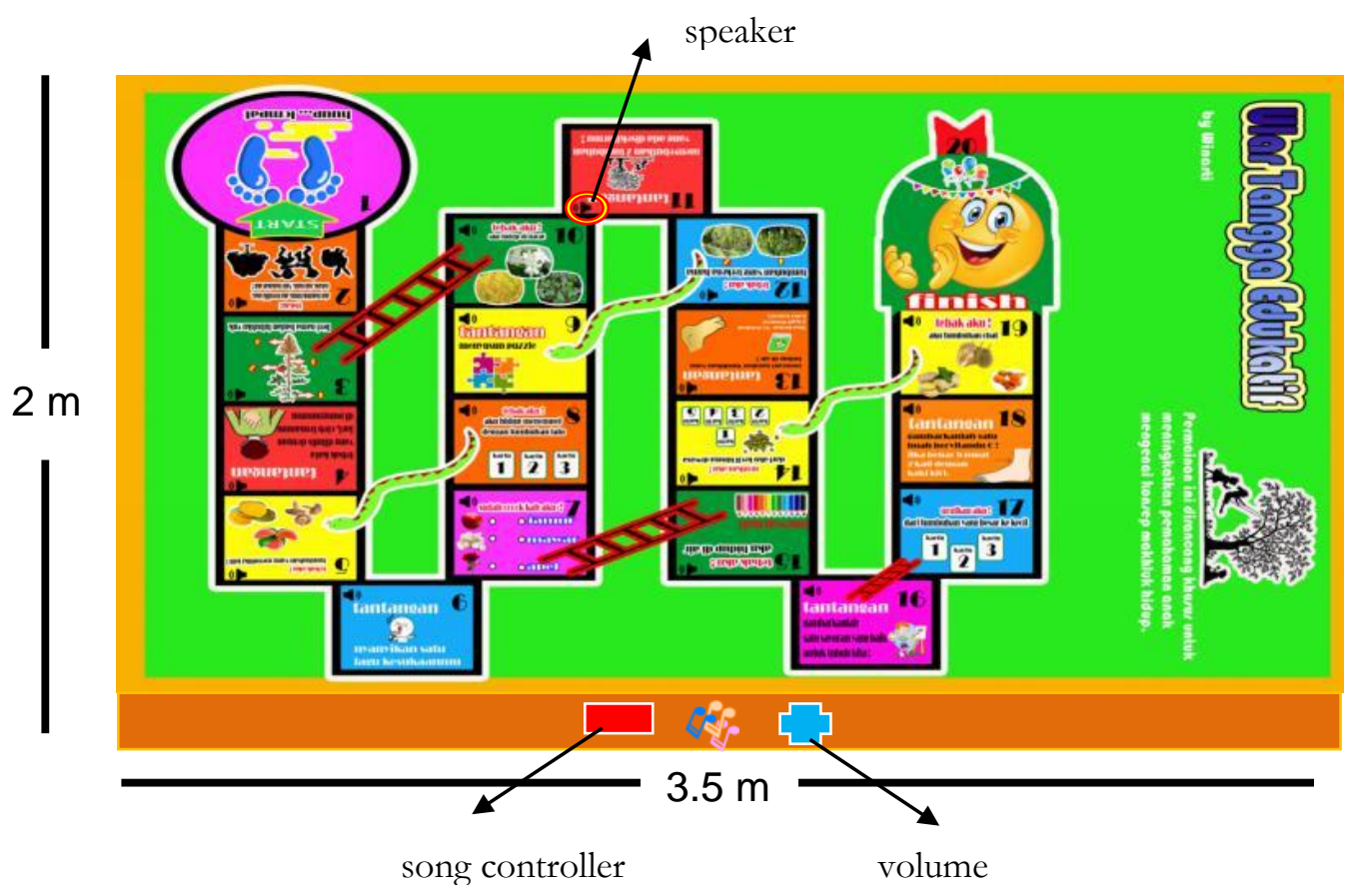


Figure 1 Educative Snakes And Ladders Board Game With Plants Subtheme

In the box number $2,3,5,7,10,15$, and 19 are placed answer keys that can be opened and closed with adhesive.
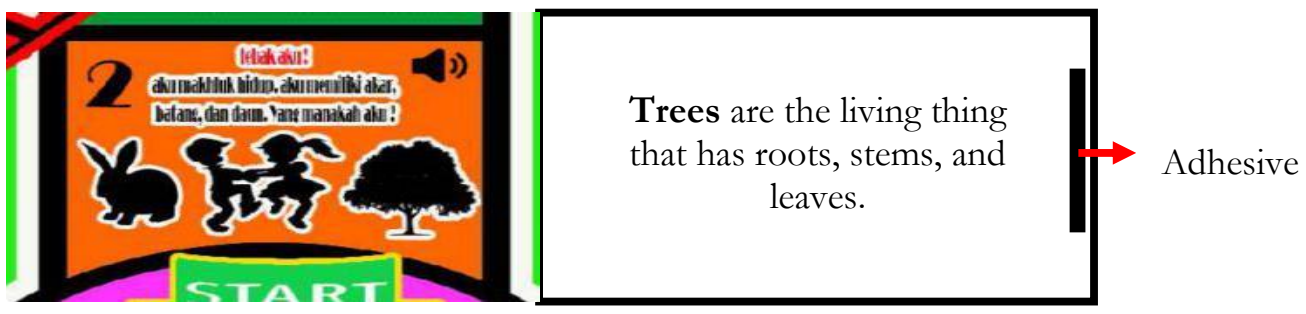

Figure 2. Description of box number 2 of the educative snakes and ladders board game with plants subtheme

In the box number $8,12,13,14,15,16,17,18$ are placed cards, puzzles, and activity sheets in coloring paper and a paper to draw an image from the jumping frog figure that can be opened and closed with adhesive

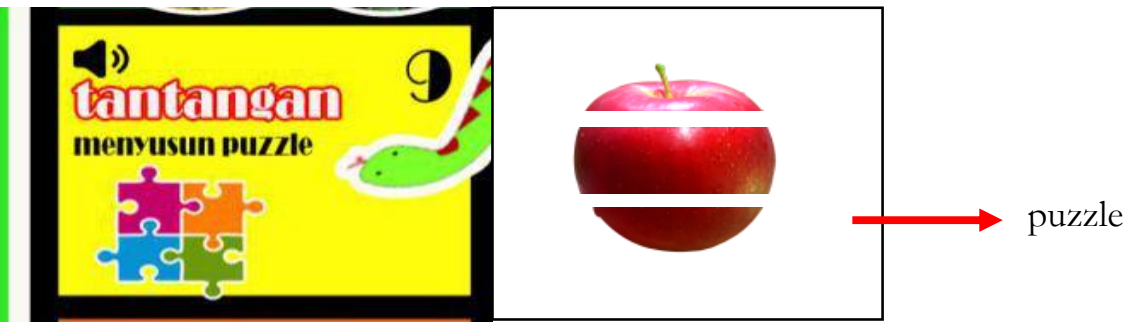

Figure 3. Box Number 9 of the Educative Snakes and Ladders Board Game with Plants Subtheme

The pawns for this game are the players.
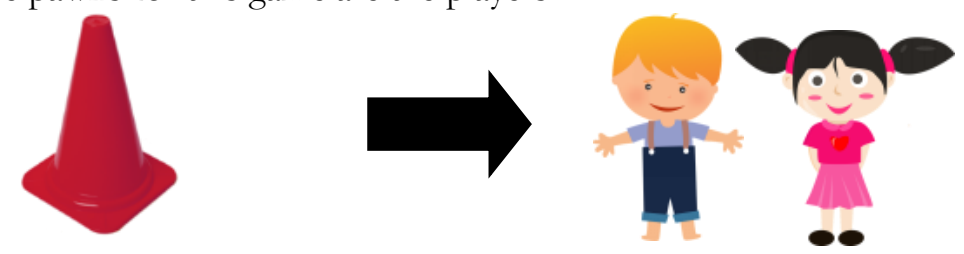

Figure 4. The Pawns for the Educative Snakes and Ladders Board Game with Plants Subtheme

The dice was made of flannel base material which has geometry shape of circles, squares, and triangles on top of it
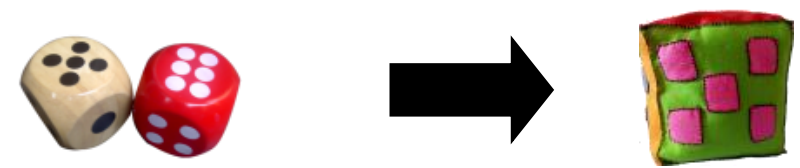

Figure 5. The Dice for the Educative Snakes and Ladders Board Game with Plants Subtheme 
(2) Description for the box of educative snakes and ladders board game with plants subtheme Box Number

Box Indicator Box Description

\begin{tabular}{cll}
\hline 1 & Start here ! & $\begin{array}{l}\text { Children are divided into groups, each of them as one } \\
\text { chance to roll the dice. The person who has the highest } \\
\text { numbers will stand in the box number 1 "START HERE } \\
\text { !" and it follows the players' time arrangement. }\end{array}$ \\
\hline $2 \quad \begin{array}{l}\text { Guess who I am ! } \\
\text { I'm a living thing, I have }\end{array}$ & $\begin{array}{l}\text { There are silhouette of : } \\
\text { roots, stems, fruits, and }\end{array}$ \\
leaves. Which one am i? & $\begin{array}{l}\text { - A boy and a girl } \\
\text { - Tree }\end{array}$
\end{tabular}

The living thing that has characteristics of having roots, stems, fruits, and leaves is Tree.

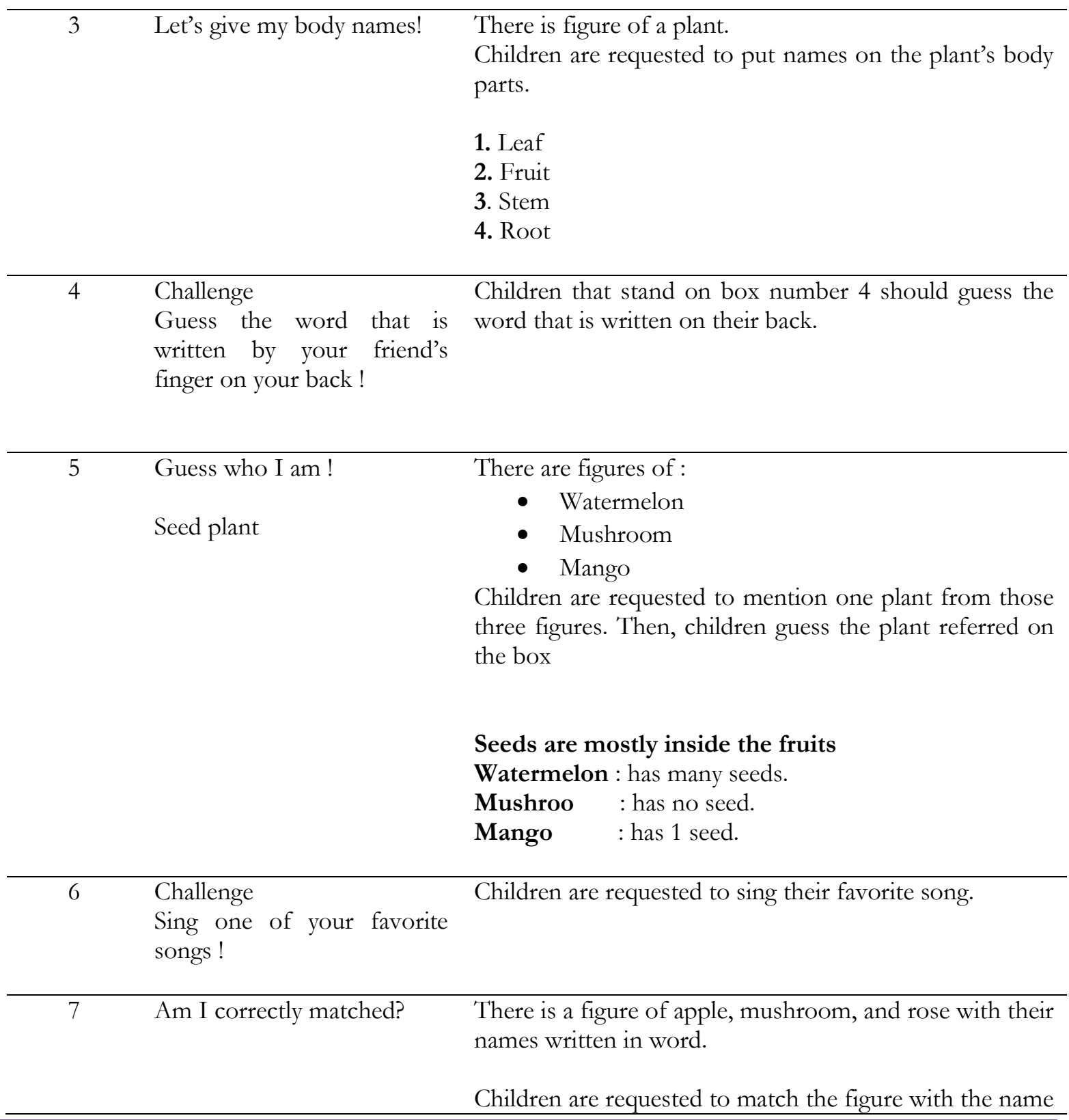


with the provided ribbon on the back of the box.

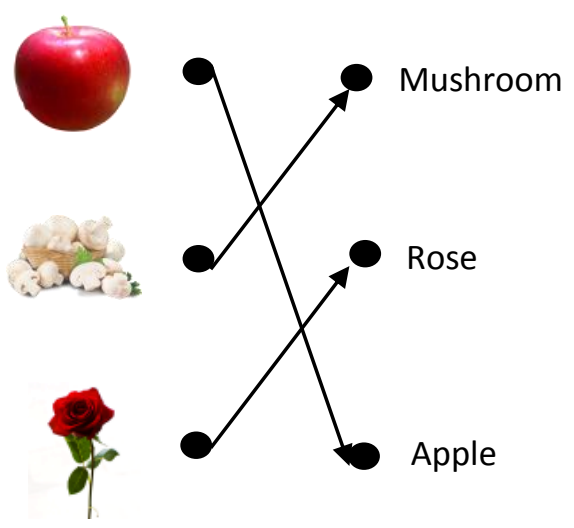

\begin{tabular}{ll}
\hline $\begin{array}{l}\text { Guess who I am } ! \\
\text { I live by sticking with the } \\
\text { other plants. }\end{array}$ & $\begin{array}{l}\text { There are three drawing cards which are: } \\
\text { Card } 1 \text { figure of lotus } \\
\text { Card } 2 \text { figure of fern and orchid } \\
\text { Card } 3 \text { figure of mango tree }\end{array}$ \\
& $\begin{array}{l}\text { Children are requested to chose the figure that matched } \\
\text { to the description on the box. }\end{array}$ \\
& $\begin{array}{l}\text { Plant that live together with the other plant is card } \\
\text { number } 2 \text { which consists of a figure of fern and } \\
\text { orchid }\end{array}$
\end{tabular}

$9 \quad$ Challenge

Put the puzzles in order Children are requested to put the puzzle in order, then mention the name of plant on the figure

Papaya is a plant that has many seeds in its fruit.

\begin{tabular}{|c|c|c|}
\hline 10 & $\begin{array}{l}\text { Guess who I am! } \\
\text { I live on the land }\end{array}$ & $\begin{array}{l}\text { There are figures of : } \\
\text { - Jasmine } \\
\text { - Rice plant } \\
\text { - Water hyacinth }\end{array}$ \\
\hline & & $\begin{array}{l}\text { Children are requested to mention the names of the } \\
\text { plants. Then they are asked to guess the plants that are } \\
\text { matched to the description on the box. }\end{array}$ \\
\hline & & $\begin{array}{l}\text { Jasmines, live on the land tumbuh didarat } \\
\text { Rice plants, live on the land } \\
\text { Water Hyacinth, live on the water }\end{array}$ \\
\hline 11 & $\begin{array}{l}\text { Challenge } \\
\text { Mention two plants near you } \\
!\end{array}$ & $\begin{array}{l}\text { Children are requested to mention the name of the } \\
\text { plants nearby (at home, school, etc). then children are } \\
\text { asked to explain the plants' characteristics }\end{array}$ \\
\hline 12 & $\begin{array}{l}\text { Guess who I am! } \\
\text { Plants that are affected by } \\
\text { pests }\end{array}$ & $\begin{array}{l}\text { There are two figures: } \\
\text { Figure } 1 \text { is a mango tree } \\
\text { Figure } 2 \text { is orange tree }\end{array}$ \\
\hline
\end{tabular}


Children are requested to observe the two plants. Then, chose one of the matched plants.

Figure 2 is an orange tree that has been affected by pests that harmful for the plant.

13 Challenge

Find a figure of a plant that live on the water!

If it is answered correctly, jump three times with the right foot
There are 5 drawing cards, which are:

- Banana tree

- Orchid

- Water hyacinth

- Mango tree

- Lotus

Children are requested to find cards that are matched to the description in the box.

Banana tree grows on the land

Orchid grows on the land

Water hyacinth grows on the water

Mango tree grows on the land

Lotus grows on the water

There are five drawing cards

From seed to growing plant

Children are requested to mention the names of the figures in the box, then put it in order to the life cycle of green beans from the provided cards.

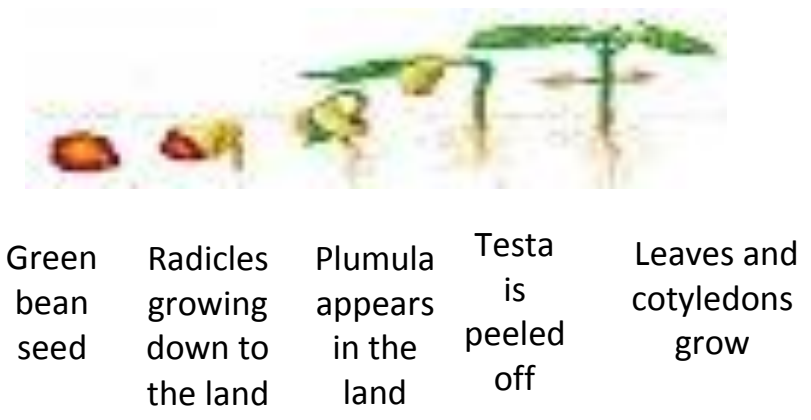

\begin{tabular}{|c|c|c|}
\hline \multirow[t]{3}{*}{15} & $\begin{array}{l}\text { Guess who I am } \\
\text { I live in the water }\end{array}$ & $\begin{array}{l}\text { There are three figures of activity which are figure of } \\
\text { lotus, orchid, and jasmine. }\end{array}$ \\
\hline & (coloring) & $\begin{array}{l}\text { Children are requested to choose a plant that live in the } \\
\text { water, then they color the chosen figure. }\end{array}$ \\
\hline & & $\begin{array}{l}\text { Lotus lives on the water } \\
\text { Orchid lives on the land } \\
\text { Jasmine lives on the land }\end{array}$ \\
\hline 16 & $\begin{array}{l}\text { Challenge } \\
\text { Draw a vegetable that is } \\
\text { good for our health! }\end{array}$ & $\begin{array}{l}\text { There are activity worksheets for the children } \\
\text { Children are requested to draw a vegetable based on the } \\
\text { description of the box, then they are asked to explain } \\
\text { about the characteristics of the vegetable. }\end{array}$ \\
\hline 17 & Put me in order! & $\begin{array}{l}\text { There are three drawing cards. } \\
\text { Those cards are consisted of figures of grass, mango tree, }\end{array}$ \\
\hline
\end{tabular}




\begin{tabular}{|c|c|c|}
\hline & $\begin{array}{l}\text { From the growing up plant } \\
\text { to the seed. }\end{array}$ & $\begin{array}{l}\text { and rose } \\
\text { Children are requested to put the cards in order based on } \\
\text { its characteristics. } \\
\text { Plant life from the grown-up to the seed is mango } \\
\text { tree, rose, and grass }\end{array}$ \\
\hline 18 & $\begin{array}{l}\text { Challenge } \\
\text { Draw a fruit that contains } \\
\text { Vitamin C! } \\
\text { If it is answered correctly, } \\
\text { jump two times with the left } \\
\text { foot. }\end{array}$ & $\begin{array}{l}\text { There is an activity worksheet for the chindren. } \\
\text { Children are requested to draw a fruit based on the } \\
\text { description in the box. }\end{array}$ \\
\hline 19 & $\begin{array}{l}\text { Guess who I am! } \\
\text { I am a medical herb }\end{array}$ & $\begin{array}{l}\text { There are figures of : } \\
\text { - Durian } \\
\text { - Ginger } \\
\text { - Turmeric } \\
\text { Children are requested to mention one plant, then they } \\
\text { are asked to guess which figure that matches to the } \\
\text { description on the box. } \\
\text { Ginger and Turmeric are medical herbs that are } \\
\text { mostly made as jamu }\end{array}$ \\
\hline 20 & Finish & Children has finished playing the game \\
\hline
\end{tabular}

2. The terms and conditions for playing the educative snakes and ladders board game with plants subtheme are here as follow:

a. This board game is played when the topic of teaching material is related to the concept of plants;

b. This game is playing in groups, every group consists of 4-5 players;

c. Players are not allowed to find the answers on the text book or other sources;

d. Teachers are the facilitator in this game, children are free to explore their knowledge;

3. Rules of the educative snakes and ladders board game with plants subtheme

Rules that should be understood before playing this game as a learning media for children in the classroom are: a. Every player has one chance to roll the dice to decide which player plays first, the child who gets the highest number will play first.

b. There are three different parts that should be followed to play this game:

1) Players are the pawns; every player should jump from one box to the other.

2) Players should read the information on the box loudly. However, if there is a problem in reading the information, children are allowed to press the speaker figure to listen to the audio. When the players step on the challenge box, they have to do the challenge. If the players have done the challenge correctly, they will get 
one point and if they don't, they will get zero point. Then, players that step on activity collection will do the given instruction on the box. The result of this game will be collected as an assessment

3) When players step on the snake box, players should follow the snake's body. If it leads the players to step on the other box, players should follow the instruction given on the box they step on.

The winner of this game is given for the group that answers challenges correctly and gets to the finish line first. When the time is over and none of groups have reached the finish line, the winner will be chosen by the last position of the players. The players that step on the highest number will be the winner. Challenge box will worth to one point, and zero point if they can not do the challenge. In the box of activity collections, there will be a performance assessment for the players.

\section{CONCLUSION}

Educative snakes and ladders board game with plants subtheme as a media for learning is specially designed to introduce the concept of plants to the students. This media learning project is based on the theoretical concept of plants, Permendiknas No. 22 Year 2006, and early childhood development program.

\section{Acknowledgement}

The researcher would like to express the gratitude to IAKN Tarutung for giving full support to this research. The researcher also wants to thank to SD Negeri Arenjaya XVIII, SD Negeri Arenjaya XIV, and SD Nederi Arenjaya II that have allowed the researcher to conduct this research.

\section{REFERENCES}

Agustriana, N. (2019). PENGARUH METODE EDUTAINMENT DAN IDENTITAS DIRI TERHADAP KETERAMPILAN SOSIAL ANAK. Al-Fitrah, 1(2), 216-
228.

https://doi.org/http://dx.doi.org/10.293

00/alfitrah.v2i1.1517

Amin, A., Wiwinda, W., Alimni, A., \& Yulyana, R. (2018). Pengembangan Materi Pendidikan Agama Islam Berbasis Model Pembelajaran Inquiry Training Untuk Karakter Kejujuran Siswa Sekolah Menengah Pertama. At-Ta'lim: Media Informasi Pendidikan Islam, 17(1), 151-160. https://doi.org/http://dx.doi.org/10.293 00/attalim.v17i1.1418

Arikunto, S. (2009). Dasar-Dasar Evaluasi Pendidikan. Jakarta: Bumi Aksara.

Borg, W. R.., Gall M.D., \& Gall, J.P. (2003). Educational Research an Introduction Seventh Edition. America: Longman.

Cahyo, A. N. (2011). Gudang Permainan Kreatif Khusus Asah Otak Kiri Anak. Yogyakarta: FlashBooks.

Irwandani, I., Umarella, S., Rahmawati, A., Meriyati, M., \& Susilowati, N. E. (2019). Interactive Multimedia Lectora Inspire Based on Problem Based Learning: Development in the Optical Equipment. Journal of Physics: Conference Series, 1155(1). https://doi.org/10.1088/17426596/1155/1/012011

Kellough, R. D. (1996). Integrating Mathematics and Science for Kindergarten and Primary Cbildren. America: A Simon \& Schuster Company.

Khoirudin, M. (2019). Pengembangan Modul Pembelajaran IPA Biologi Berbasis Scientific Approach Terintegrasi Nilai Keislaman Pada Materi Interaksi Antar Makhluk Hidup Dengan Lingkungan. IJIS Edu: Indonesian Journal of Integrated Science Education, 1(1), 33-42. https://doi.org/10.29300/ijisedu.v1i1.14 03 
Leriyono, I. K., Kurniah, N., \& Ardina, M. (2018). Media Berbasis Information and Communication Technology (ICT) Dalam Pembelajaran Sains Pada Anak Usia Dini. Jurnal Ilmiah POTENSIA, 3(2), 89-90.

https://doi.org/10.33369/JIP.3.2.89-90

Minarti, I. B., Susilowati, S. M. E., \& Indriyanti, D. R. (2012). Perangkat Pembelajaran Ipa Terpadu Bervisi Sets Berbasis Edutainment Pada Tema Pencernaan. Journal of Innovative Science Education, 1(2), 7.

Mulyatiningsih, E. (2013). Metode Penelitian Terapan di Bidang Pendidikan. Bandung: Alfabeta.

Nurjatmika, Y. (2012) Ragam Aktifitas Harian untuk TK. Yogyakarta: Diva Pres

Peraturan Menteri Nomor 22 Tahun 2006 tentang Standar Isi untuk Satuan Pendidikan Dasar dan Menengah. Standar Kompetensi dan Kompetensi Dasar. Jakarta: Badan Standar Nasional Pendidikan, 2006.

Putra, N. (2013). Research \& Development Penelitian dan Pengembangan Suatu Pengantar. Jakarta: Rajawali Pers.

Rahmawati, (2015). Hasil Trend in International Mathematics and Science Study (TIMSS): Diagnosa Hasil untuk Perbaikan Mutu dan Peningkatan Capaian. Puspendik Kemendikbud.

Sackes, M. (2014). How often Do Early Childhood Teachers Teach Science Concepts? Determinants of the Frequency of Science Teaching in Kindergarten. European Early Childhood Education Research, 22 (2), 171. https://eric.ed.gov/?q=mesut+sackes\&id $=\mathrm{EJ} 1017637$
Samatowa, U. (2010). Pembelajaran IPA di Sekolah Dasar. Jakarta: PT Indeks.

Saregar, A., Giyoto, G., Ariyani, F., Pawe, T. I., Pricilia, A., \& Astriawan, D. (2019). How to Design Physics Posters Learning Media with Islamic Values in Developing Learning Motivation and Student Character? Journal of Pbysics: Conference Series, 1155(1). https://doi.org/10.1088/17426596/1155/1/012093

Selviani, I. (2019). Pengembangan Modul Biologi Problem Based Learning Untuk Meningkatkan Kemampuan Berpikir Kritis Peserta Didik SMA. IJIS Edu: Indonesian Journal of Integrated Science Education, 1 (2). https://doi.org/10.29300/ijisedu.v1i2.20 32

Sikder, Shukla dan Marilyn Fleer. (2015). Small Science: Infants and Toodlers Experiencing Science in Everyday Family Life.(2009). Research in Science Education, 45 (3), 446. http://dx.doi.org/10.1007/s11422-0189869-x

Sujiono, Y. N. (2009). Konsep Dasar Pendidikan Anak Usia Dini. Jakarta: PT Indeks.

Vlach, H. A. \& Noll, N. (2016). Talking to Children about Science is Harder than We Think: Characteristis and Metacognitive Judgments of Explanations Provided to Children and Adults. Metacognition Learning, $11 \quad$ (3), 317. http://dx.doi.org/10.1007/s11409-0169153-y

Wheatley, B. C., Gerde, H.K. \& Cabell, S.Q. (2016). Integrating Early Writing Into Science Instruction in Preschool. The Reading Teacher: International Literacy 
Association, $\quad 70 \quad(1), \quad 83$.

http://dx.doi.org/10.1002/trtr.1470 